\title{
An Innovative Marketing Strategy to Promote our College of IT: Zayed University Case Study
}

\author{
Manar Abu Talib and \\ May El Barachi \\ Zayed University, Abu Dhabi, UAE \\ manar.abutalib@zu.ac.ae \\ may.elbarachi@zu.ac.ae
}

\author{
Olga Ormandjieva \\ Concordia University, \\ Montreal, Canada
}

ormandi@cs.concordia.ca

\begin{abstract}
The College of Information Technology (CIT) at Zayed University seeks to produce graduates recognized by business, government, and educational entities in the United Arab Emirates, the Gulf region, and the rest of the world as having a sound, current, and comprehensive education in IT. However, the enrollment of the CIT is limited, compared to other colleges. Two surveys have revealed the importance of introducing the CIT to young male and female students before they decide on their major field of study. In this paper, we present the marketing strategy followed by our CIT, based on presentations to students in the COL 105 (Career Exploration) and COL 270 (Introduction to IT) courses, which prepare them well for "Majors Day" and other high profile IT events they can attend. This marketing strategy is designed to increase the students' knowledge about the CIT, especially those who have no background in computing. Our proposed strategy is inspiring them to spend more time learning about the CIT, and a population growth study has shown promising results and an increase in enrollment since the fall of 2010. In addition, we include a set of suggestions and recommendations on how to enhance this strategy.
\end{abstract}

Keywords: Information Technology education, University College, survey, marketing strategy, population growth study.

\section{Introduction}

Low student enrollment in the computing fields has always been an issue in universities all over the world. A great deal of research has been conducted and many studies published to address the challenges faced by those institutions, the reasons for the low enrollment, and the possible approaches to improving and increasing that enrollment. However, there is still a concern about the consistently small number of students choosing computing as their major. For example, a recent study has shown that enrollment has dropped $60 \%$ over the last 4 years in the field of computer

Material published as part of this publication, either online or in print, is copyrighted by the Informing Science Institute. Permission to make digital or paper copy of part or all of these works for personal or classroom use is granted without fee provided that the copies are not made or distributed for profit or commercial advantage AND that copies: 1) bear this notice in full; and 2) give the full citation on the first page. It is permissible to abstract these works so long as credit is given. To copy in all other cases or to republish or post on a server, or to redistribute to lists, requires specific permission and payment of a fee. Contact Publisher@InformingScience.org to request redistribution permission. science (Carter, 2006). The top tier universities are also suffering from the same problem. As suggested in (Carter, 2006), low enrollment could be related to the availability of jobs or to lack of student awareness about these fields and the subjects taught, or both. Another reason could be gender-related (Carter, 2006). At the same time numerous solutions have been put forward. Some researchers point to the curriculum content 
in a child's early education. For instance, the Computer Science Teachers Association (CSTA) has introduced the Model Curriculum for K-12 Computer Science education (CSTA, 2003), which would certainly increase the amount of knowledge imparted to youngsters about the computing fields at an early age. Other researchers addressed the problem from a different point of view, which was to design a process for a non major computing course (Guzdial \& Forte, 2005). In spite of the substantial effort expended to motivate female students to enter the computing fields, there is a common perception, and statistics bear this out, that computing is more suitable for males (Fisher, Margolis, \& and Miller, 1997), (Force, 2008). In a previous study (Abu Talib \& El Barachi, 2011), we carried out a detailed survey among the female student population at Zayed University in the UAE. It was administered to students before they joined a particular college, to students at the 200 level enrolled at the CIT, and to senior students enrolled at the CIT. The purpose of the survey was to understand the challenges faced by our College of IT in attracting female students, and to implement an approach to increase their enrollment at the college. In this paper, we propose a marketing strategy, as well as a set of supporting marketing activities, to promote the college. We were aware of the importance of having a team in place dedicated to this task in order to obtain effective results. Our team consisted of four faculty members, who coordinate with the CIT administrators to make a difference in the female enrollment.

The rest of this paper is organized as follows: In the next two sections, we present a brief literature review and the profile of the CIT at Zayed University in Abu Dhabi. Section 4 provides an overview of the marketing strategy applied by our CIT. It details the marketing activities in which the CIT is involved, such as presentations to students taking COL 105 (a second semester course on career exploration) and COL 270 (a third semester course introducing IT), Majors Day, and Expo Week. In addition, we present two surveys: one on population growth (section 5), and one on suggestions and recommendations for enhancing our marketing strategy (introduced in section 6). Finally, our conclusions and directions for future work are presented in section 7.

\section{Literature Review}

In spite of the remarkable effort expended to encourage students to enter the computing fields, there are a number of obstacles in the way. Many researchers have discussed the influence of guidance counselors on students' decisions regarding their major prior entering the CIT, and a recent study indicates that the counselors themselves lack knowledge about the computing fields and the related job market. Moreover, they don't have sufficient time to inform students about the opportunities available in computing (Saunders \& Hunsinger, 2008). Since guidance counselors might have a great impact on these students, it is well worth talking to them about the computing fields and the job prospects for computing graduates, and the need to set aside sufficient time to discuss a future in computing with these students before they enter the college and decide on a major. Other positive contributions have been made by students at Carnegie Mellon University, their first initiative generating an outreach presentation that answers two main questions: "Who can be a computer scientist?" and "What can you do with a computer science degree?” Their second initiative is a weekly series of technology skills workshops, called "Creative Technology Nights for Girls.” These initiatives are planned and presented by female students and cover a range of topics, such as Web page design and building a website, computer illustration, programming, 2-D animation, robot design and robot programming, Internet safety, virtual world construction, programming through visual storytelling, and using Photoshop and Illustrator, as well as social events like Movie Nights, Open Houses, etc. In this way, they challenge stereotypes and promote new images for computer science and its related disciplines (Frieze \& Treat, 2006). It is also worth noting that Stanford University has put in place strategies over the past ten years designed to increase the enrollment of female students in computer science at the undergraduate level. The principal components of that effort are as follows: 1) redesign the introductory sequence to make it accessible to a much wider audience; 2) provide role models for undergraduate 
women at every stage of the educational process; 3) establish bridge programs for female students, and also minorities, who are at greater risk of leaving the technical fields; and 4) establish a program to engage undergraduates in faculty research (Roberts, Kassianidou, \& Irani, 2003).

\section{CIT Profile}

The College of Information Technology (CIT) seeks to produce graduates recognized by business, government, and educational entities in the United Arab Emirates, the Gulf region, and the rest of the world as having a sound, current, and comprehensive education in information technology systems (ZU, 2012). This mission runs parallel to the aim of Abu Dhabi Vision 2030 (Masdar, 2011), (ADW, 2010), which is to ensure that Abu Dhabi has one of the top five governments in the world by 2030. IT plays a vital role in any government, and the work of information technology professionals is essential for effective operations in today's knowledge-based society (ZU, 2012). As a result, and to help fulfill the vision of the Emirate, our college has undertaken to attract more students to the computing fields. The CIT meets with public and private sector representatives to update the IT curricula and majors to meet their needs. For example, the CIT has established a new specialization, Enterprise Computing, which is also important to the success of Abu Dhabi Vision 2030, as this initiative will rely on smart use of IT in all its key areas. All the services provided to the community by Abu Dhabi government enterprises (e.g. Emirates ID Authority, Health Authority of Abu Dhabi) need IT professionals. For example, the Health Authority of Abu Dhabi is considering adopting Cloud Computing, and this is one of the new courses offered within the Enterprise Computing specialization. Similarly, the Municipality of Abu Dhabi is developing Knowledge Management Systems, which is another new course offered by the college. Clearly, the college has already built bridges to help meet market needs, and so does not have this problem, which is described in many recent studies.

Zayed University has one campus in Abu Dhabi and another in Dubai. At each one, female students are separated from male students, which is why we have two buildings for delivering academic programs to these students. We have five colleges: College of Arts and Science, College of Business Sciences, College of Communication \& Media Sciences, College of Education, and College of Information Technology, as well as University College. In a previous study (Abu Talib \& El Barachi, 2011). We conducted a survey among 68 female students on the Abu Dhabi Campus, who took the course COL105 in the fall of 2010. Our aim was to determine their level of awareness about the CIT. The results show that almost half do not have enough information about the colleges, and there could be other factors affecting their decision about whether or not to enroll. The results also show that the primary factors the majority of students (around 72\%) considered when deciding on their major were their interests and strengths. Moreover, they indicate that the female students have certain perceptions about the IT field, that it is highly academically challenging, for example, and heavily math-oriented, that it offers mostly jobs as technicians, and that it involves a great deal of programming and many hours in front of a PC. Finally, we were curious to know whether or not they had made their choice about what major to select at this stage. In fact, half the students had decided to join the College of Arts and Science or the College of Business Science, and only $10 \%$ of them had decided to join the College of Information Technology. However, the good news is that $28 \%$ of the students still hadn't decided on their major, and so we think we were right to approach University College and encourage them to build a bridge between their students and the CIT, with a view to talking with students about our college and introducing them to the opportunities it offers (Abu Talib \& El Barachi, 2011).

The CIT has limited enrollment, compared to that of other colleges at Zayed University. As a result, in this paper, we focus on the marketing strategy we have designed to correct the perceptions of the female students at Zayed University. We have also implemented this strategy among the 
male students, to determine whether or not their perceptions are the same as those of the female students.

\section{The Marketing Strategy}

In December 2010, a pilot marketing committee was formed on the Abu Dhabi campus at the request of the Associate Dean to achieve certain goals (Abu Talib, 2011). The primary goal of this committee is to increase the visibility of the college and generate interest among pre-major students in the IT field. The second goal is to maintain an ongoing promotional effort to boost CIT enrollment. The third goal is to develop and put in place a structured framework for college-wide promotional activities. The committee consists of four faculty members who work closely with the rest of the college to ensure that these goals are achieved. They began by developing a marketing strategy for the CIT, which is illustrated in Figure 1.

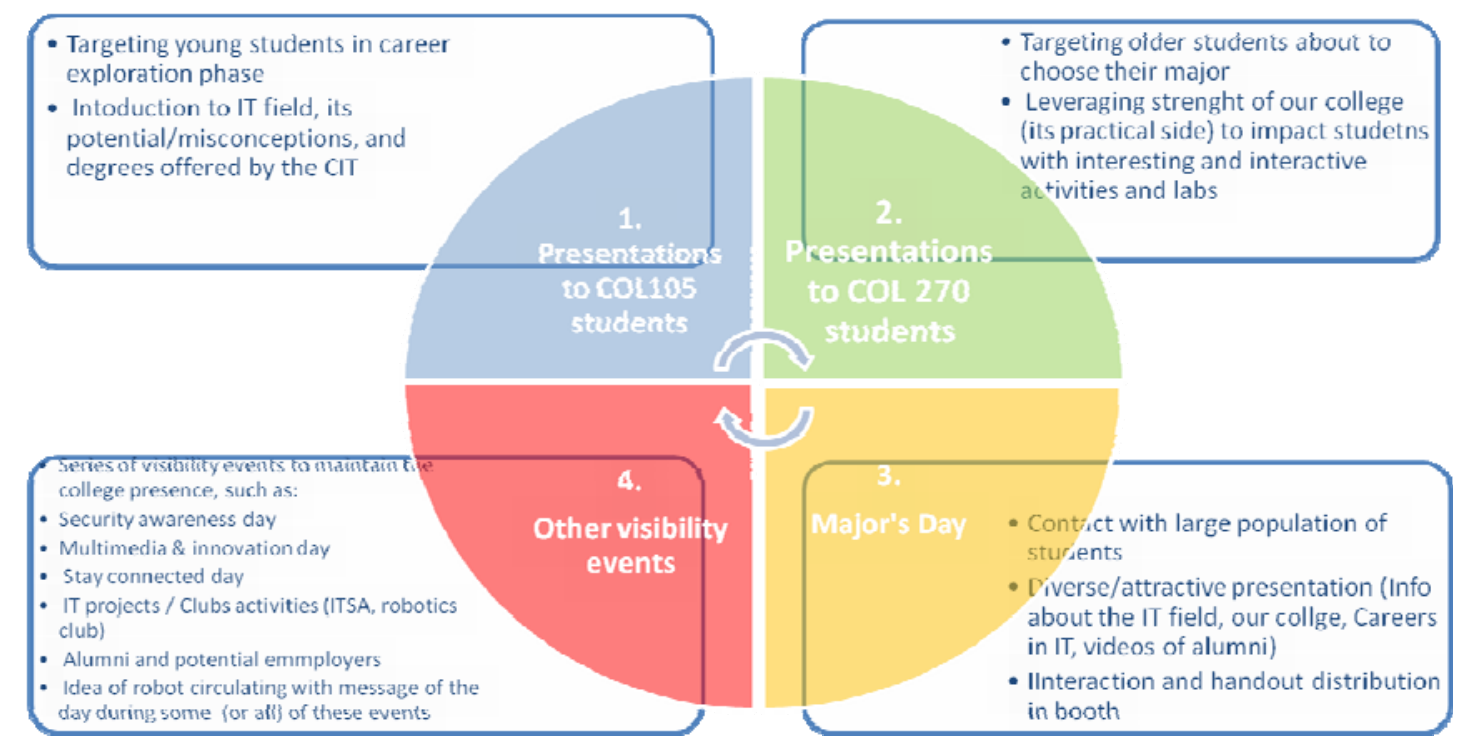

Figure 1: CIT Marketing Strategy

As shown in the figure, this iterative marketing strategy considers two categories of activities:

- Targeted one-on-one presentations involving close interaction with pre-major students registered in COL105 and COL270, as means to increase their awareness about the IT field and the CIT program offerings;

- University-wide events intended for the entire student body of ZU, as a means to raise the college's profile. Also included is the Majors Day event.

In the subsections below, we describe the activities related to these categories.

\section{COL 105 Presentations}

COL 105 students are in their second semester and engaged in career exploration. Towards the end of this semester, the students will enroll in their pre-major course(s). These presentations provide a key opportunity to influence students in their selection of a major.

The idea behind them is to create a strong positive link with the University College students who are taking this career exploration course, and raise their awareness about employment in the IT 
field, its potential, and the misconceptions associated with it; our college; and the degrees it offers. The following activities were conducted during the academic year 2010-2011:

- Prepared and made presentations to two COL 105 sections during the Fall 2010 semester, and 2 COL 105 sections during the Spring 2011 semester.

- Conducted a survey before and after the presentation.

- Followed up with the COL 105 instructors.

- Videotaped the presentation so that the COL 105 instructors could reuse it.

- Developed materials based on the COL 105 presentation feedback to be shared with the students on Majors Day. Met with the same students again on Majors Day to reinforce the message.

- Sent a message to the students in insideZU, the university's online magazine, after Majors Day to maintain contact with them.

The marketing committee's continuing efforts to reach the male students are also reported in this paper. The survey was carried our during the Spring 2011 semester for 42 male students, as part of the COL 105 presentation series. The results are similar to those we obtained on the female student survey. They show that most of the students enjoyed the presentation delivered by the marketing committee. There was high degree of interaction during the activity, and the male students were encouraged to ask questions during and after the presentation. This enabled them to show an interest in the CIT and learn more about it. Actually, 95\% of them felt that they learned something new and interesting about the CIT. Around $46 \%$ of them expressed an interest in the field, and felt that IT training is needed and that everyone should have some IT background. Networking and Security was the most attractive field for our male students. In the last section of the survey, the students were encouraged to provide additional comments, some examples of which are the following: "The information was presented well," "It was a good presentation, I enjoyed it very much," and "I would really like to enroll at the CIT. Thanks for your help." 
An Innovative Marketing Strategy to Promote IT College: Zayed University Case Study

COL 105 presentation (Male Students)

\begin{tabular}{l|l|l|l|} 
Respondents: & 42 displayed, 42 total & Statusi & Open \\
Launched Date: & N/A & Closed Date: & N/A \\
\cline { 2 - 4 } Displary: & Page 1 & Manage Filters \\
\hline
\end{tabular}

1. What do you think of todsy's presentation?

\begin{tabular}{|c|c|c|c|c|c|}
\hline & & $\begin{array}{l}\text { Response } \\
\text { Total }\end{array}$ & $\begin{array}{l}\text { Response } \\
\text { Percent }\end{array}$ & Points & Avg \\
\hline OK & & 2 & $5 \%$ & $\mathrm{n} / \mathrm{a}$ & $\mathrm{n} / \mathrm{a}$ \\
\hline Good & & 7 & $17 \%$ & $\mathrm{n} / \mathrm{a}$ & $\mathrm{n} / \mathrm{a}$ \\
\hline Very Good & & 15 & $36 \%$ & $\mathrm{n} / \mathrm{a}$ & $\mathrm{n} / \mathrm{a}$ \\
\hline \multirow[t]{3}{*}{ Excellent } & & 18 & $43 \%$ & $\mathrm{n} / \mathrm{a}$ & $\mathrm{n} / \mathrm{a}$ \\
\hline & Total Respondents & 42 & $100 \%$ & & \\
\hline & \multicolumn{4}{|c|}{ View conditional responses (if applicable) } & view \\
\hline
\end{tabular}

2. Did you learn some interesting and new stuff about the $\Pi$ College?

\begin{tabular}{|c|c|c|c|c|c|}
\hline & & $\begin{array}{c}\text { Response } \\
\text { Total }\end{array}$ & $\begin{array}{c}\text { Response } \\
\text { Percent }\end{array}$ & Points & Avg \\
\hline$Y=s$ & & 40 & $95 \%$ & $\mathrm{n} / \mathrm{a}$ & $\mathrm{n} / \mathrm{a}$ \\
\hline \multirow[t]{2}{*}{ No } & & 2 & $5 \%$ & $\mathrm{n} / \mathrm{a}$ & $\mathrm{n} / \mathrm{a}$ \\
\hline & Total F & spondents & 42 & & \\
\hline
\end{tabular}

3. After today's presentation, IT College is:

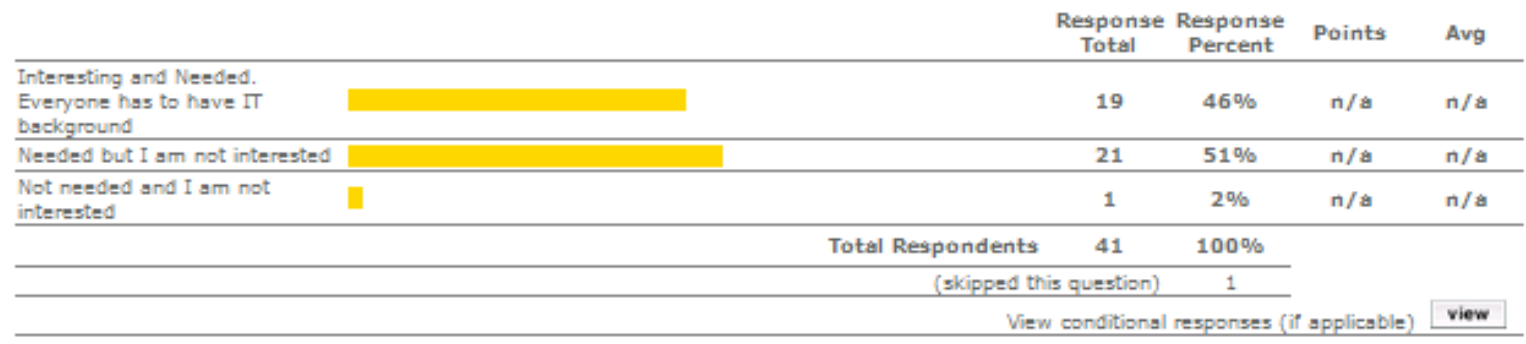

4. What attracts you most from the $\Pi$ College offerings?(You can choose more than one)

\begin{tabular}{|c|c|c|c|c|}
\hline & $\begin{array}{l}\text { Response } \\
\text { Total }\end{array}$ & $\begin{array}{l}\text { Response } \\
\text { Percent }\end{array}$ & Points & Avg \\
\hline Networking and Security Major & 23 & $55 \%$ & $\mathrm{n} / \mathrm{a}$ & $\mathrm{n} / \mathrm{a}$ \\
\hline IT Strategic Management Major & 6 & $14 \%$ & $\mathrm{n} / \mathrm{a}$ & $\mathrm{n} / \mathrm{a}$ \\
\hline Joint degres: $\Pi \mathrm{T}$ \&. Business & 21 & $50 \%$ & $\mathrm{n} / \mathrm{a}$ & $\mathrm{n} / \mathrm{a}$ \\
\hline Joint degree: $\Pi$ \& Education & 7 & $17 \%$ & $\mathrm{n} / \mathrm{a}$ & $\mathrm{n} / \mathrm{a}$ \\
\hline Joint degree: $\Pi \mathrm{B}$. Multimedia & 17 & $40 \%$ & $\mathrm{n} / \mathrm{a}$ & $\mathrm{n} / \mathrm{a}$ \\
\hline $\begin{array}{l}\text { IT Minor in Interactive Social } \\
\text { Computing }\end{array}$ & 10 & $24 \%$ & $\mathrm{n} / \mathrm{a}$ & $\mathrm{n} / \mathrm{a}$ \\
\hline IT Minor in Information Systems & 10 & $24 \%$ & $\mathrm{n} / \mathrm{a}$ & $\mathrm{n} / \mathrm{a}$ \\
\hline
\end{tabular}

Figure 2: University College survey results (42 male students) - 1 
COL 105 presentation (Male Students)

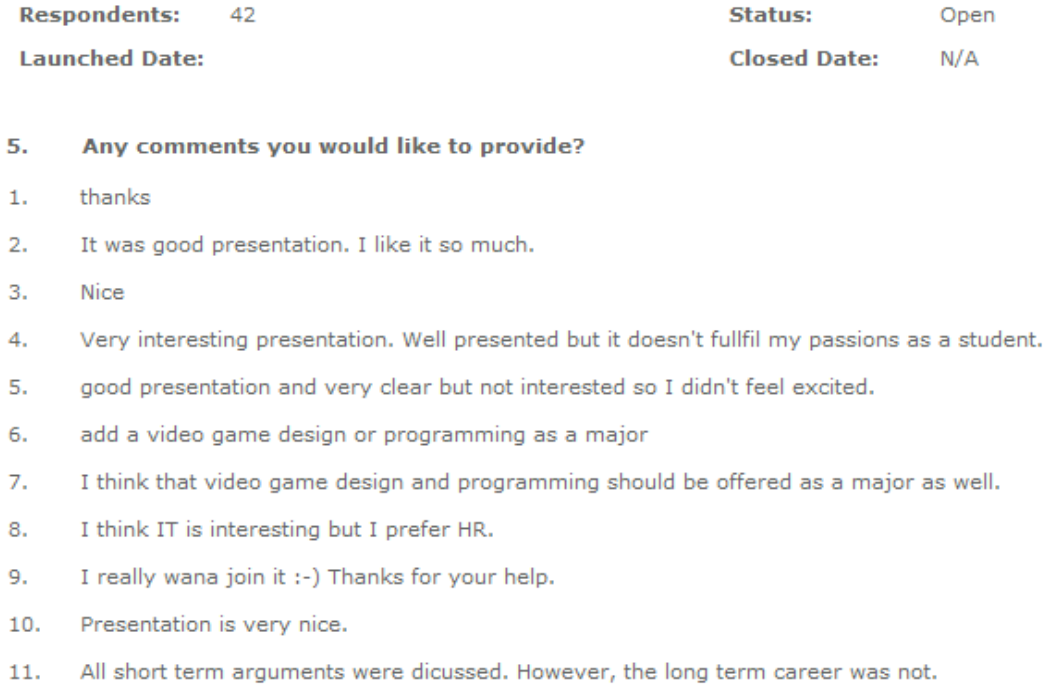

Figure 3: University College Survey Results (42 male students) - 2

\section{COL 270 Presentations}

COL 270 students are in their third semester. In the latter part of it, students apply for their major. The goal of this intensive collaboration with COL 270 instructors is to leverage the strength of our college (i.e. its practical side) to impress the students with the interesting and interactive labs and activities offered. This is an opportunity either to confirm a student's selection of a major in IT or to sway an undecided student to choose to major in IT.

After a number of meetings and discussions with the COL 270 instructors, the following plan (Table 1) and schedule for the presentations and activities was put together for the Spring 2011 semester. One member of the marketing committee undertook to coordinate with all the CIT and University College faculty involved to oversee the successful execution of this plan.

Table 1 COL 270 Plan

\begin{tabular}{|c|c|c|}
\hline COL 270 Chapters & $\begin{array}{l}\text { Complementary } \\
\text { areas by CIT }\end{array}$ & Detailed Topics Delivered by CIT \\
\hline \multicolumn{3}{|c|}{ Chapter 1: Information Technology, the internet and You } \\
\hline \multicolumn{3}{|c|}{ Chapter 2: The internet, the web, and Electronic Commerce } \\
\hline \multicolumn{3}{|l|}{ Chapter 3: Basic Application Software } \\
\hline Chapter 4: Specialized Application Software & Multimedia & $\begin{array}{l}\text { 1. Introducing Multimedia Lab } \\
\text { 2. Overview of multimedia project creation process } \\
\text { 3. How to create an avatar - COL } 270 \text { students } \\
\text { could customize it }\end{array}$ \\
\hline Chapter 5: System Software & Mobile Applications & \\
\hline Chapter 6: The System Unit & Hardware & $\begin{array}{l}\text { 1. Components identification } \\
\text { 2. PC assembly simulation } \\
\text { 3. Laptop assembly simulation }\end{array}$ \\
\hline Chapter 7: Input and Output & Hardware & 4. Q\&A session \\
\hline \multicolumn{3}{|l|}{ Chapter 8: Secondary Storage } \\
\hline Chapter 9: Communication and Networks & Network & \\
\hline Chapter 10: Privacy and Security & Security & $\begin{array}{l}\text { 1. Downloading a fake game that we pack- } \\
\text { aged...once installed we're able to control their } \\
\text { machine (NetBus) } \\
\text { 2. Uncovering a deleted photo from a Nokia phone } \\
\text { 3. Finding the location information of a photo } \\
\text { 4. Reading login information from RAM } \\
\text { 5. Managing cookies }\end{array}$ \\
\hline
\end{tabular}




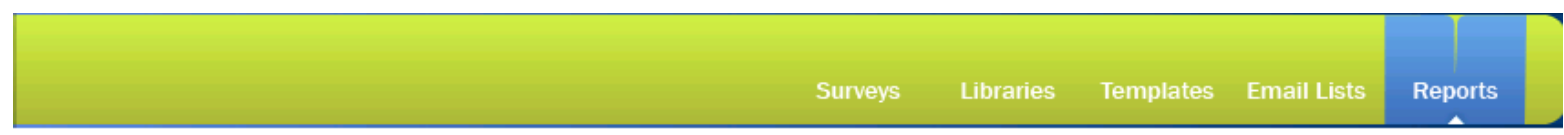

\section{Results Overview}

PRINT OVERVIEW :INDIVIDUAL RESPONSES EXPORT DATA

COL270/CIT collaboration survey - Spring 2011

\begin{tabular}{|c|c|c|c|c|}
\hline Respondents: & 100 displayed, 100 total & Status: & \multicolumn{2}{|l|}{ Open } \\
\hline Launched Date: & N/A & Closed Date: & \multicolumn{2}{|c|}{$06 / 14 / 2011$} \\
\hline Display: & Page 1 & $\nabla$ & Manage Filters & 0 filters \\
\hline \multicolumn{3}{|c|}{ Active Report Filters: None Active. } & Share Results & Disabled \\
\hline
\end{tabular}

1. In general, what do you think of the College of IT activities/demos carried during the COL270 course?

\begin{tabular}{|c|c|c|c|c|c|}
\hline & & $\begin{array}{c}\text { Response } \\
\text { Total }\end{array}$ & $\begin{array}{c}\text { Response } \\
\text { Percent }\end{array}$ & Points & Avg \\
\hline OK & & 22 & $22 \%$ & $n / a$ & $n / a$ \\
\hline Good & & 44 & $44 \%$ & $n / a$ & $\mathbf{n} / \mathbf{a}$ \\
\hline Very Good & & 22 & $22 \%$ & n/a & $\mathbf{n} / \mathbf{a}$ \\
\hline \multirow[t]{3}{*}{ Excellent } & & 12 & $12 \%$ & $n / a$ & n/a \\
\hline & Total Respondents & 100 & $100 \%$ & & \\
\hline & \multicolumn{4}{|c|}{ View conditional responses (if applicable) } & view \\
\hline
\end{tabular}

2. Which activity/demo did you like the most? (You can choose more than one)

\begin{tabular}{|c|c|c|c|c|c|}
\hline & & $\begin{array}{c}\text { Response } \\
\text { Total }\end{array}$ & $\begin{array}{c}\text { Response } \\
\text { Percent }\end{array}$ & Points & Avg \\
\hline Multimedia activity & & 59 & $59 \%$ & $n / a$ & $n / a$ \\
\hline Security \& privacy activity & & 37 & $37 \%$ & $\mathbf{n} / \mathbf{a}$ & $n / a$ \\
\hline PC hardware activity & & 17 & $17 \%$ & $n / a$ & $\mathrm{n} / \mathrm{a}$ \\
\hline \multirow[t]{2}{*}{ Networking activity } & & 30 & $30 \%$ & $\mathbf{n} / \mathbf{a}$ & $\mathrm{n} / \mathrm{a}$ \\
\hline & Total Respondents & 100 & & & \\
\hline
\end{tabular}

View conditional responses (if applicable) view

\begin{tabular}{|c|c|c|c|c|c|}
\hline & & $\begin{array}{c}\text { Response } \\
\text { Total }\end{array}$ & $\begin{array}{c}\text { Response } \\
\text { Percent }\end{array}$ & Points & Avg \\
\hline Multimedia & & 42 & $42 \%$ & $n / a$ & $n / a$ \\
\hline Security & & 35 & $35 \%$ & n/a & $n / a$ \\
\hline PC hardware & & 3 & $3 \%$ & $\mathrm{n} / \mathrm{a}$ & $n / a$ \\
\hline Networking & & 12 & $12 \%$ & $\mathrm{n} / \mathrm{a}$ & $n / a$ \\
\hline \multirow[t]{2}{*}{ None of the above } & & 8 & $\mathbf{8} \%$ & $n / a$ & $n / a$ \\
\hline & Total Respondents & 100 & $100 \%$ & & \\
\hline
\end{tabular}

4. Which major have you chosen, and in which college?

View responses to this question view Total Respondents 99

(skipped this question) 1

5. What are the most important factors that affected your decision when choosing your major, 1 being the most important and 5 being the 5. What are the most important factors that affected your decision when choosing your major, 1 being the most important and 5 bein
least importanse Response

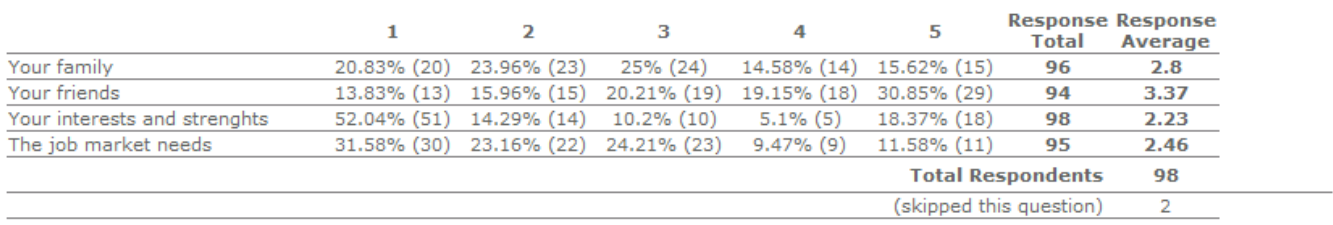

6. Would you like to provide any comments ?

View responses to this question view

Total Respondents

(skipped this question)

Figure 4: COL 270 survey results (100 female students) 
Figure 4 shows the results of the surveys conducted during the COL 270 presentations (Spring 2011) to gauge their impact and effectiveness. One hundred students completed the survey: $12 \%$ of them found the CIT activities and demos to be excellent, and $22 \%$ found them to be very good; $44 \%$ of the students found the activities to be good, while $22 \%$ found them just okay. The second question asked in the survey concerned the activity best liked by the students. The results show that around 59\% of them enjoyed the multimedia activity the most, and around 37\% ranked the security and privacy activity second. The networking activity was a close third, around 30\% of the students enjoying it, and the PC hardware activity was least enjoyable according to around $17 \%$ of the students. The multimedia and security topics were the most popular among the COL270 students. The following comments were provided by the students at the end of the survey: "The session was useful," "I found it very interesting," "Good activities," "I would like to have more classes like this," "This is a very useful course, which helped me understand a complicated subject. I think I learned the basics, which is very good,” etc.

\section{Majors Day}

Majors Day is organized to allow all the Zayed University colleges to communicate with the students. The aim of the event is to help the students decide on their major area of study by listening to the presentations made by the colleges and talking with the faculty and students at each college. In addition, booths are set up to display college brochures, handouts, and videos. In the fall of 2010, two faculty members from the marketing committee delivered a Majors Day presentation on the Abu Dhabi and Dubai campuses. This new, student-friendly presentation seemed to appeal to the students, based on the results we obtained from the surveys. Most importantly, it addressed the students' concerns that we collected in the survey studies. The presentation also highlighted the college programs and IT careers open to graduates in each specialization. During the Spring 2011 and Fall 2011 semesters, the faculty repeated the exercise for both the male and the female students on the Abu Dhabi campus, with some enhancements to the presentation. The committee added an overview of two new minors and one new major; added two videos about CIT alumni; added a video about Zayed University's Abu Dhabi Police Forensics alumni; invited two IT managers, one from the Abu Dhabi Systems and Information Center (ADSIC) and the other from the Al Hilal Bank, to talk to students at the end of the presentation; invited the IT Student Association (ITSA) and the Robotics clubs to assist at the booth during the day; and, finally, updated the presentation for the male students.

Figures 5 and 6, which were a part of the Majors Day presentation, answer the most two frequently asked questions by the University College students. These figures were also published in insideZU:

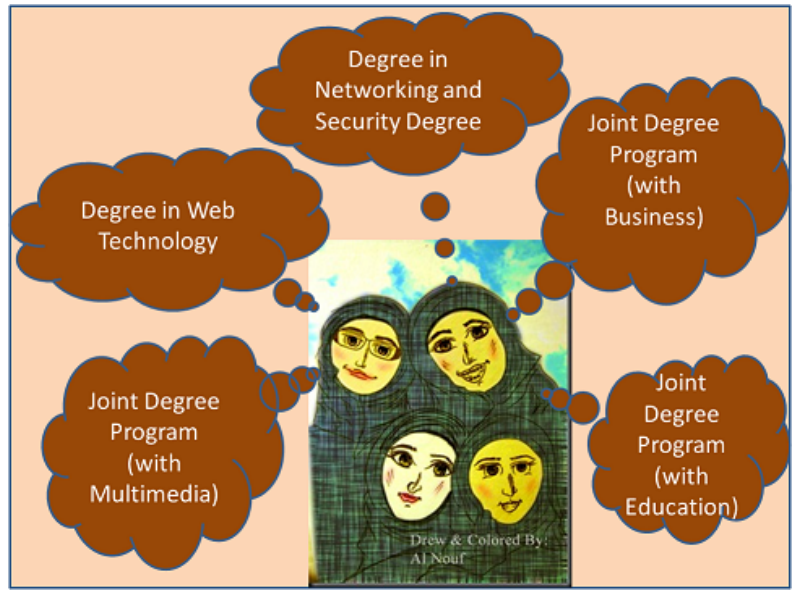

Figure 5: What programs does the College of IT offer? 


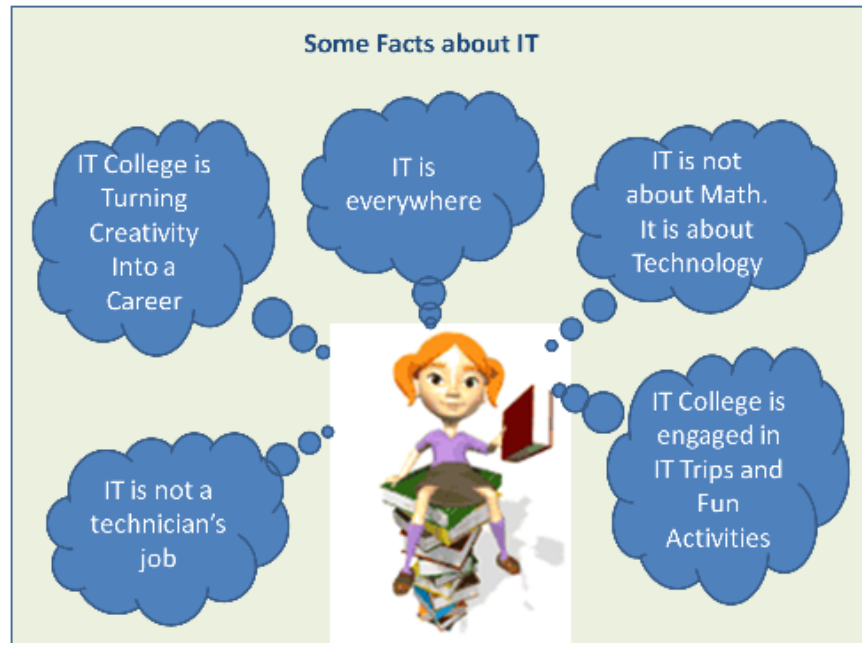

Figure 6: What is IT?

\section{Expo Week}

To raise the visibility of the CIT to the Zayed University student community, the Associate Dean proposed the idea of an Expo Week to showcase the CIT. The goal of this activity was to create a positive image of the IT major among pre-major students by showcasing the very interesting work our students produce in the classroom and in the laboratory. It also allowed non IT students see what an IT major is all about, and why it is beneficial to study IT as a major. The format was the following:

- Three or four booths available all day, particularly from 10 a.m. to 2 p.m.

- Booths available for use by students to present their work related to topics studied at the CIT: posters, live demos, power point presentations, games.

- Focus on visual/interactive things.

- Possible installation of a moving robot in the exhibition area to attract attention.

The topics for the booths included: security awareness, ethical hacking, digital forensics, multimedia and innovation, getting connected with networking, getting to know your PC hardware components, ITSA club activities/projects, and robotics club activities/projects.

The schedule for Expo Week is shown in the Figure 7.

Expo Week was a great success, and attracted a large audience. The marketing committee believes it achieved its goal of putting the work and activities of CIT students on display and demonstrating their skills to the wider Zayed University community. 


\begin{tabular}{|c|c|c|c|c|c|}
\hline & $\begin{array}{l}\text { Sunday } \\
(22 / 05 / 2011)\end{array}$ & $\begin{array}{l}\text { Monday } \\
\text { (23/05/2011) }\end{array}$ & $\begin{array}{l}\text { Tuesday } \\
(24 / 05 / 2011)\end{array}$ & $\begin{array}{l}\text { Wednesday } \\
(25 / 05 / 2011)\end{array}$ & $\begin{array}{l}\text { Thursday } \\
(26 / 05 / 2011)\end{array}$ \\
\hline $\begin{array}{c}\text { Booth } \\
\# 1\end{array}$ & $\begin{array}{l}\text { Hardware } \\
\text { Booth } \\
\text { (Faculty } \\
\text { member) }\end{array}$ & $\begin{array}{l}\text { Hardware } \\
\text { Booth } \\
\text { (Faculty } \\
\text { member) }\end{array}$ & \multirow{4}{*}{ 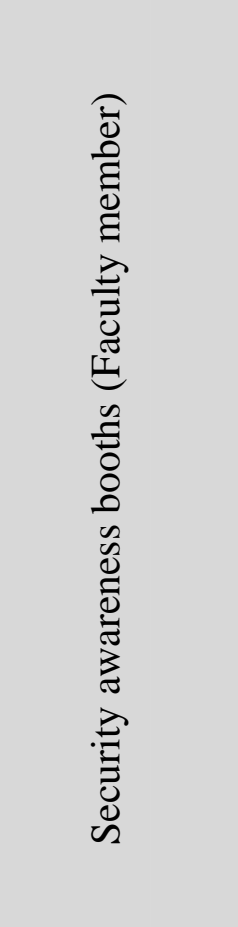 } & \multirow{4}{*}{ 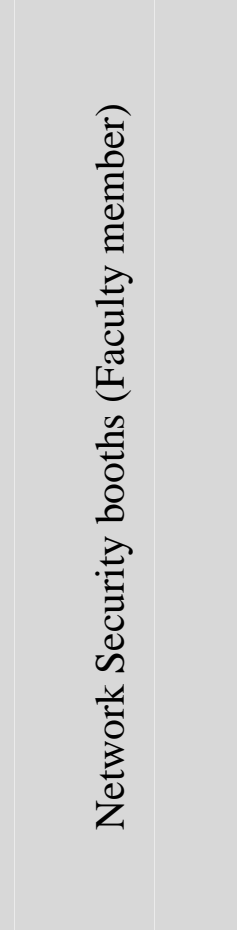 } & $\begin{array}{l}\text { ITSA club booths } \\
\text { (Projects/activities) }\end{array}$ \\
\hline $\begin{array}{c}\text { Booth } \\
\# 2\end{array}$ & $\begin{array}{l}\text { Ethical } \\
\text { hacking } \\
\text { (Faculty } \\
\text { member) }\end{array}$ & $\begin{array}{l}\text { Ethical } \\
\text { hacking } \\
\text { (Faculty } \\
\text { member) }\end{array}$ & & & $\begin{array}{l}\text { ITSA club booths } \\
\text { (Projects/activities) }\end{array}$ \\
\hline $\begin{array}{c}\text { Booth } \\
\text { \# } 3\end{array}$ & $\begin{array}{l}\text { Multimedia } \\
\text { booth } \\
\text { (Faculty } \\
\text { member) }\end{array}$ & $\begin{array}{l}\text { Multimedia } \\
\text { booth } \\
\text { (Faculty } \\
\text { member) }\end{array}$ & & & $\begin{array}{l}\text { Robotics club } \\
\text { booths (Pro- } \\
\text { jects/activities) }\end{array}$ \\
\hline $\begin{array}{c}\text { Booth } \\
\# 4\end{array}$ & \multicolumn{2}{|c|}{$\begin{array}{l}\text { Merlin Computers (Cool } \\
\text { computer equipment and } \\
\text { gadgets) }\end{array}$} & & & $\begin{array}{l}\text { Robotics club } \\
\text { booths (Pro- } \\
\text { jects/activities) }\end{array}$ \\
\hline
\end{tabular}

Figure 7: Expo Week schedule

\section{Population Growth Study}

The figures in Table2 show the recent CIT enrollment on the Abu Dhabi campus, which has increased since the start of the marketing effort in the fall of 2010. CIT 210, Introduction to IT and Systems, is the first required course in the CIT curriculum, which students from other colleges can take as an elective. We expect this number to grow more quickly, as we refine and enhance our marketing activities.

Table 2 Population Growth Study in CIT

\begin{tabular}{|l|c|c|}
\hline Abu Dhabi & $\begin{array}{l}\text { New majors } \\
\text { (females) }\end{array}$ & $\begin{array}{l}\text { New majors } \\
\text { (males) }\end{array}$ \\
\hline Cohort 16 Fall 2009 & 19 & 10 \\
\hline Cohort 17 Spring 2010 & 17 & 11 \\
\hline Cohort 18 Fall 2010 & $\mathbf{2 8}$ & $\mathbf{9}$ \\
\hline Cohort 19 Spring 2011 & $\mathbf{3 3}$ & $\mathbf{8}$ \\
\hline Cohort 20 Fall 2011 & $\mathbf{3 9}$ & $\mathbf{9}$ \\
\hline Cohort 21 Spring 2012 & $\mathbf{7 3}$ & $\mathbf{3 2}$ \\
\hline
\end{tabular}




\section{Suggestions for Enhancing the Marketing Strategy}

Although the proposed marketing strategy shows promising results, we have added a set of suggestions in this section to improve it even more. This pilot should be extended as a sustainable marketing plan to both campuses under the auspices of a college marketing committee, since activities and events should be uniform across both campuses. The committee should meet at least monthly and report to the Dean's Office. The workload for events and activities organized by the committee for this important and strategic college function should be distributed among all faculty members, as it is in everyone's interest for this strategy to be an unqualified success. If everyone contributes a little time and effort, the CIT can achieve a great deal. Such marketing contributions can be made part of the annual faculty evaluation under services, in this case to the CIT, i.e. every faculty member records what he or she did to contribute to the enrollment of students at the College of IT.

Table 3 lists ongoing activities and suggestions for the refinement and enhancement of CIT marketing to pre-major students for the Fall 2011 semester and beyond:

\section{Table 3. Ongoing activities and Suggestions}

\section{Activity/Suggested course of action}

\section{COL105 Presentations}

These will be continued, and expanded to cover all sections. They will be conducted by teams of two faculty members, and recorded as services to the CIT. The presentations will be enhanced to cover such topics as:

o Why the faculty members made IT their career choice

o What majors IT offers

o The academic challenges of IT as a major

o Why IT is a good major

o The skills/qualities needed to be successful with IT as a major

0 The challenges of an IT career

0 Where to find work in IT in AUH/DXB

\section{CIT-COL 105 Communication}

Bridges will be built with COL105 instructors based on CIT activities, events, and curriculum/career information updates, so that the students can participate. COL105 surveys can be enhanced and repeated during future semesters.

\section{COL 105 Student Meetings}

Faculty members will make themselves available as advisors to students, to address their concerns.

\section{COL 270 Presentations}

These presentations will cover three areas only: security, enterprise computing, and multimedia. They will be delivered prior to the students' deadline for declaring their major, and coordinated by COL 270 instructors. 


\section{Majors Day}

CIT alumni and one IT employer can be invited to talk to the students. The content of these lectures will complement that of the COL105 presentations. Up-to-date versions of CIT brochures, student posters, course posters, and ITSA and Robotics club posters will be available to the students, along with issues of insideZU and newspapers.

\section{Student Expo Week}

This event will be coordinated by the marketing committee and student clubs, and may include a booth that could be manned by a different IT employer each day.

\section{CIT Posters}

A high profile for the CIT is created with posters about IT specializations, student clubs, IT topics (e.g. What is Cloud Computing?), which would mostly consist of diagrams, images, and a small amount of text, faculty posters of research presented, etc.

\section{Video Collection}

Abu Dhabi and Dubai alumni, as well as internship sites will be asked to contribute videos to the collection. These can be used on Majors Day and on request from the COL 105 and COL 270 instructors to provide career information and job links for IT specializations.

\section{insidezU}

The goal of this online publication is to inform and update University College students about the CIT.

\section{Industry Speakers}

It has been suggested that speakers be invited on a monthly basis to give talks on current IT topics. All members of the ZU community are invited to attend.

\section{IT Competition}

This competition is open to Zayed University students only, and might offer 5 different student categories: $1^{\text {st }} \mathrm{yr}, 2^{\text {nd }} \mathrm{yr}, 3^{\text {rd }} \mathrm{yr}, 4^{\text {th }} \mathrm{yr}$, and IT major. Possible competition names: Amazing IT, IT for the UAE, Practical IT, etc.

\section{Conclusions and Future Work}

The aim of Abu Dhabi Vision 2030 is to ensure that Abu Dhabi has one of the top five governments in the world by 2030. IT plays a vital role in running any government, and our College of IT is doing its best to attract more students to this field and help the objectives of Abu Dhabi Vision 2030 to be met. In this paper, we introduced the College of IT marketing strategy, which consists of four elements: presentations to COL 105 students, presentations to COL 270 students, Majors Day, and other high profile events. The population growth study showed that the results of the strategy are promising, and that it should be become even more successful, in terms of student enrolment at the CIT. Finally, we presented our suggestions and recommendations for the proposed marketing strategy. Our future work will include improving the strategy and conducting an ongoing study of the growth of the student population at the CIT. 


\section{Acknowledgments}

We thank the College of IT team at Zayed University, and especially Dean Leon Jololian and Associate Dean Anthony Rhodes, who helped us carry out this study and provided significant feedback.

\section{References}

Abu Talib, M., \& El Barachi, M. (2011). Revitalizing the IT college: A case study. In Proceedings of the 2nd Conference on Technology Management (MCTM - 2011). Dubai, UAE.

ADW. (2010, September 22). Abu Dhabi Vision 2030 -- Looking to the future. Retrieved September 15, 2011, from Abu Dhabi Week http://www.abudhabiweek.ae/component/content/article/159-this-is-abudhabi/3558-plan-abu-dhabi-2030-looking-to-the-future?directory=234\&Itemid=234

Carter, L. (2006). Why students with an apparent aptitude for computer science don't choose to major in computer science. Proceedings of the 37th SIGCSE Technical Symposium on Computer Science Education (SIGCSE '06). Houston, Texas, USA.

CSTA. (2003). A model curriculum for K-12 computer science: Final report of the ACM K-12 Task Force. USA: ACM.

Fisher, A., Margolis, J., \& Miller, F. (1997). Undergraduate women in computer science: Experience, motivation and culture. Proceedings of the 28th SIGCSE Technical Symposium on Computer Science Education (SIGCSE 1997). San Jose, CA, USA.

Force, I. D. (2008). IST strategic plan: Building the brand through partnership networks for excellence. University Park.

Frieze, C., \& Treat, E. (2006). Diversifying the images of computer science: Carnegie Mellon students take on the challenge! USA: Proceedings of Women in Engineering Programs and Advocates Network (WEPAN) Conference.

Guzdial, M., \& Forte, A. (2005). Design process for a non-majors computing course. Proceedings of the 36th SIGCSE Technical Symposium on Computer Science Education (SIGCSE’05). St. Louis, Missouri, USA.

Masdar. (2011). The Abu Dhabi Economic Vision 2030. Retrieved September 15, 2011, from The Government of Abu Dhabi http://www.masdarcity.ae/userfiles/files/economic-vision-2030-executivesummary-mandate2.pdf

Roberts, E. S., Kassianidou, M., \& Irani, L. (2003). Encouraging women in computer science. Stanford, CA.

Saunders, M. L., \& Hunsinger, D. S. (2008). Encouraging students to choose a computer-related major: The influence of guidance counselors. Boone, USA: Information Systems Education Conference.

ZU. (2011). College of Information Technology. Retrieved September 15, 2011, from Zayed University: http://www.zu.ac.ae/main/en/colleges/colleges/college_information_technology/index.aspx 


\section{Biographies}

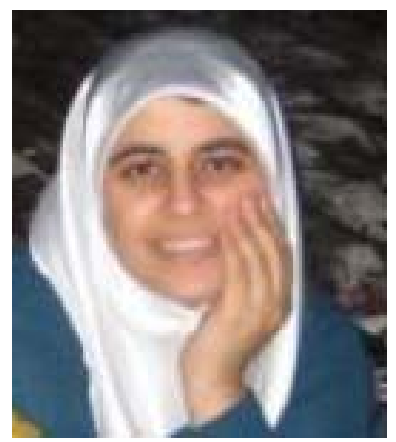

Manar Abu Talib is an Assistant Professor in the College of Information Technology at Zayed University, Abu Dhabi. She received her $\mathrm{PhD}$ in Computer Science and Software Engineering from Concordia University, Montreal, Canada, in 2007. Dr. Abu Talib’s research interest include software engineering with substantial experience and knowledge in conducting research in software measurement, software quality and in real-time systems analysis, design, and testing. Her Teaching interests are Programming, Web Development, Information Security, Software Engineering, Software Measurement, Software Quality and Software Testing and Entrepreneurship. She is working on ISO standards for measuring the functional size of software, and has been involved in developing the Arabic version of ISO 19761 (COSMIC-FFP measurement method) at Zayed University. She has an impressive list of papers to her credit, which have most recently been accepted by journals in Canada, Italy, and Germany.

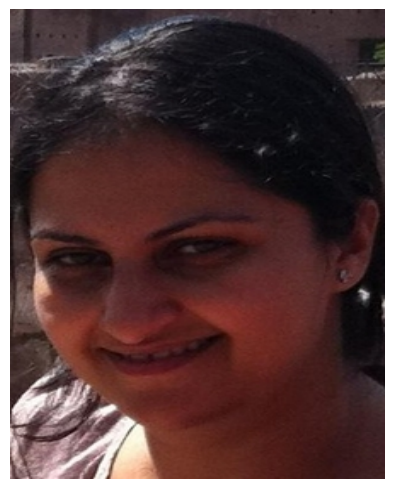

May El Barachi holds a Ph.D. and a Masters degree in Electrical and Computer Engineering from Concordia University (Canada) and a Bachelor degree in Electronics and Telecommunications Engineering from the Arab Academy for Science and Technology (Egypt). She carried her masters and doctoral research as part of an industry/academia cooperation program established between R\&D Ericsson Canada and Concordia University, and participated in several projects related to key areas in the networking field within that program. She was also part of the IST Ambient Networks project - a European Union (EU) 6th framework project, and worked as a Postdoctoral fellow at the University of Quebec - School of Superior technology (ETS). Presently, she is an assistant professor at Zayed University (UAE). Her current research interests include: service engineering; quality of service and adaptive resource management, context-awareness, web services, virtual networks, wireless sensor networks, and next generation networks. In these areas, she has authored many peer-reviewed papers and has one accepted patent.

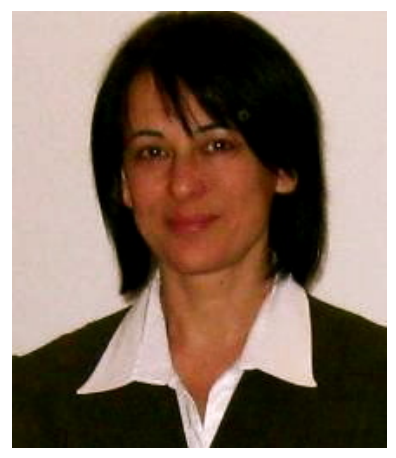

Dr. Olga Ormandjieva is Associate Professor in the Computer Science and Software Engineering department at Concordia University, Montreal, Quebec (Canada). She is also a member of the Ordre des Ingénieurs du Québec (OIQ). She has a Ph.D. in Science Degree (2002) and Master's Degree in Computer Science and Mathematics (1987). The main area of research of Dr. Ormandjieva is Measurement in Software Engineering and its extension to the development of formal methods for modeling and monitoring of reactive autonomic systems? functional and non-functional features with category theory. Her strategy for research and publications has been to create strong foundations for independent research, publish in top workshops and conferences supported by IEEE and ACM, and then target international good quality journals in the field. Currently Dr. Ormandjieva is teaching software engineering undergraduate and graduate courses at Concordia University. 